Ordene las letras en las siguientes palabras para escribir los nombres de algunos alimentos saludables. Después coloque cada una de las letras numeradas en los espacios indicados abajo para descifrar el mensaje.

\section{PRODUCTOS LÁCTEOS}

H L E E C

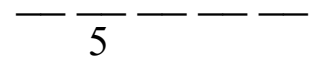

O E Q S U<smiles>C[IH]</smiles>

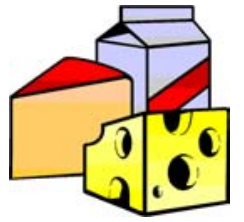

FUENTES DE PROTEÍNA

S A C O D E P

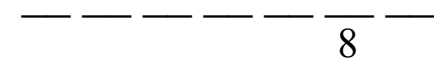

O S H V E U 14

L S I F J R O E

VEGETALES

L A C Z A A B A 12

S V R A E A J

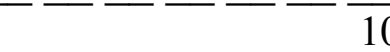

FRUTAS

S U A V

A R F S E S

M A D A N R N A I
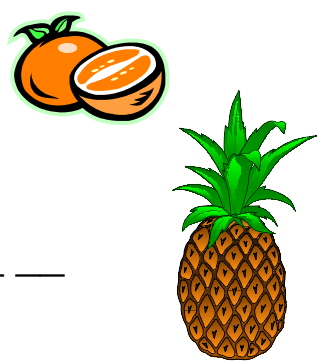

PAN, CEREAL, ARROZ, PASTA Y VIANDA

L A T R O I T L

SFDIE

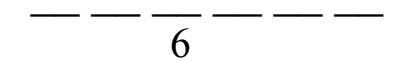

E V N A A
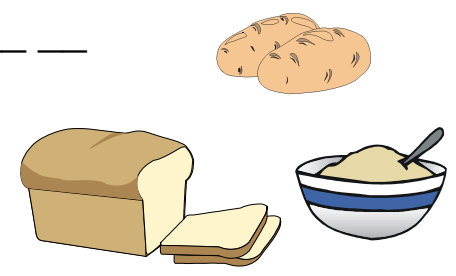

\title{
MENSAJE:
}

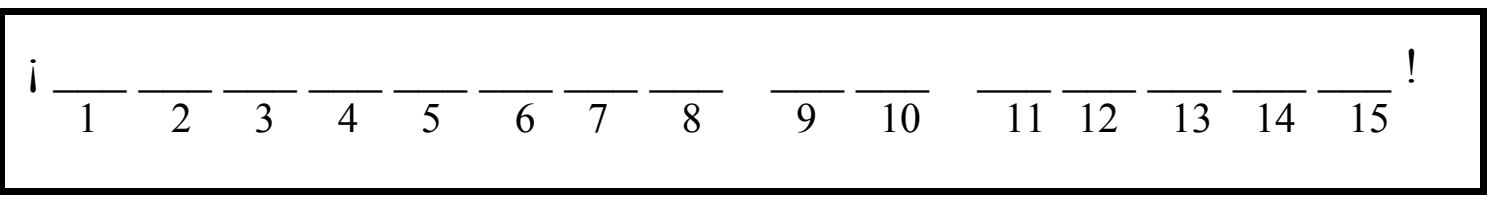

1. This is document FCS8615-SPAN, one in a series of the Department of Family, Youth and Community Sciences, Florida Cooperative Extension Service, Institute of Food and Agricultural Sciences, University of Florida, Gainesville, FL 32611. Publication date: March 2004. This leaflet was developed with funding from the Florida Department of Elder Affairs in partnership with state, county, and local agencies. Please visit the EDIS Web site at http://edis.ifas.ufl.edu

2. Leaflet design by Paulina Wittkowsky, MS, RD, former education assistant, Department of Family, Youth and Community Services, Institute of Food and Agricultural Sciences, University of Florida, Gainesville, FL 32611. English version reviewed by Linda B. Bobroff, PhD, RD, LD/N, professor, University of Florida. 